\title{
PERANCANGAN SISTEM INFORMASI PEMESANAN DAN PENJUALAN PADA TOKO HISDU GORDYN TANGERANG
}

\author{
Iqbal Fadilah ${ }^{1}$, Sutan Mohammad Arif ${ }^{2}$, Wisdariah $^{3}$ \\ 1,2,3 Teknik Informatika, Fakultas Teknik dan Ilmu Komputer, Universitas Indraprasta PGRI \\ Jalan Raya Tengah No 80, Kelurahan Gedong, Pasar Rebo, Jakarta Timur \\ 1. iqbalfdlh29@gmail.com, ${ }^{2}$ cutans.muhars@gmail.com, ${ }^{3}$ fwisdariah@gmail.com
}

\begin{abstract}
ABSTRAK
Sistem informasi pada Toko Interior Hisdu Gordyn masih melakukan pengolahan data secara manual. Pengolahan data penjualan dilakukan secara tertulis dengan menggunakan buku penjualan harian sehingga mengakibatkan barang yang terjual tidak tercatat pada buku, dikarenakan sering tidak terkonfirmasinya penjualan kepada pemegang buku persediaan yang masih juga bersifat manual. Hal ini juga mengakibatkan sering terjadinya selisih antara persediaan fisik dengan persediaan tercatat. Sehingga informasi mengenai persediaan barang menjadi tidak cocok dan tidak akurat. Tujuan penelitian adalah dengan dibuatnya aplikasi penjualan ini semua yang berhubungan dengan data penjualan pada Toko Hisdu Gordyn dapat berjalan baik dan lancar. Pada aplikasi ini, bagian admin dapat menangani pekerjaan pengolahan data barang, data petugas, riwayat transaksi. Dan petugas dapat melakukan pengolahan data pelanggan dan melakukan pemesanan dan transaksi. Data penjualan dapat digunakan dengan efisien dan akurat serta dapat di update dengan mudah. Dan dengan tercapainya sistem informasi ini bisa mempermudah kegiatan yang akan dilakui yang sangat diperlukannya cepat dan tepatnya dari pencapaian dari sistem informasi ini, kejujuran dan kedisiplinan dari petugas yang mengoperasikan sistem sangat penting untuk pengoperasiannya. Dengan adanya aplikasi sistem informasi penjualan ini membawa dampak yang baik terhadap Toko Interior Hisdu Gordyn, karena efektifitas dan efisien dapat tercapai dalam hal pengerjaan persediaan stok barang yang terkomputerisasi dan penyatuan secara baik.
\end{abstract}

Kata Kunci: Sistem Informasi, Pemesanan dan Penjualan, Java

\begin{abstract}
The information system at Hisdu Gordyn Interior Store still performs data processing manually. Sales data processing is carried out in writing using the daily sales book, resulting in the goods being sold not being recorded on the books, because sales are often not confirmed to the inventory book holders which are still manual. This also results in frequent discrepancies between physical inventories and recorded inventories. So that information about inventory becomes inappropriate and inaccurate. The purpose of the research is to make this sales application, everything related to sales data at the Hisdu Gordyn Store can run well and smoothly. In this application, the admin section can handle the work of processing item data, officer data, transaction history. And officers can process customer data and place orders and transactions. Sales data can be used efficiently and accurately and can be updated easily. And with the achievement of this information system, it can facilitate the activities to be carried out which are needed quickly and precisely from the achievement of this information system, honesty and discipline of the officers who operate the system are very important for its operation. With the application of this sales information system, it has a good impact on the Hisdu Gordyn Interior Store, because effectiveness and efficiency can be achieved in terms of computerized inventory of goods and good integration.
\end{abstract}

Key Word: Information Systems, Ordering and Sales, Java

\section{PENDAHULUAN}

Pada saat ini, Sistem infromasi berbasis komputer kini sudah menjadi hal yang penting bagi kebutuhan pemenuhan informasi. Sistem infromasi berbasis komputer telah dimanfaatkan oleh banyak bidang untuk mempermudah pekerjaan, baik pendidikan, perusahaan dagang, ataupun jasa. Perkembangan teknologi berefek pada orang banyak untuk mencari penyelesaian masalah di bidang sistem informasi. Komputer dirasa dapat membantu dan memiliki segudang keunggulan karena bisa diprogram dan disesuaikan oleh penggunanya sendiri.

Sistem informasi yang tepat mewujudkan hal yang begitu penting bagi perusahaan untuk mencapai apa yang ditargetkan. Informasi yang cepat, tepat, dan akurat akan diperoleh jika mempunyai sistem yang tepat. Oleh sebab itu sistem informasi yang tepat harus dibuat agar perusahaan dapat menjadi lebih modern dan maju. 
Bahasa pemrograman sudah sangat maju saat ini, bahasa pemrograman yang bisa dipilih oleh programer untuk membangun sebuah sistem informasi. Java adalah bahasa yang paling diminati sekarang. Dan aplikasi yang menggunakan bahasa pemrograman Java adalah Netbeans IDE.

Salah satu proses yang sangat membutuhkan adanya penerapan sistem informasi adalah penjualan. Perusahaan atau pelaku usaha yang sudah di level atas mungkin sudah memakai sistem informasi yang mereka miliki. Akan tetapi sebaliknya, perusahaan atau wirausaha menengah ke bawah mungkin saja belum atau bahkan sangat jarang yang memakai sistem informasi berbasis komputer.

Toko Interior Hisdu Gordyn masih melakukan pengolahan data secara manual. Pengolahan data penjualan dilakukan secara tertulis dengan menggunakan buku penjualan harian sehingga mengakibatkan barang yang terjual tidak tercatat pada buku, dikarenakan sering tidak terkonfirmasinya penjualan kepada pemegang buku persediaan yang masih juga bersifat manual. Hal ini juga mengakibatkan sering terjadinya selisih antara persediaan fisik dengan persediaan tercatat. Sehingga informasi mengenai persediaan barang menjadi tidak tepat dan tidak akurat. Dalam penelitian ini, penulis ingin membuat rancangan sistem informasi penjualan dengan judul "Perancangan Sistem Informasi Pemesanan dan Penjualan pada Toko Interior Hisdu Gordyn Tangerang Berbasis Java".

Perancangan adalah sebuah proses yang memiliki arti sesuatu yang akan dilakukan dengan memakai teknik yang beragam serta di dalamnya menaitkan penjelasan tentang detail bagian dan juga batas yang akan didalami dalam langkah pengerjaannya (Rizky, 2011).

Sistem adalah terdiri dari komponenkomponen yang kemudian dirangkai menjadi saling keterkaitan satu dengan lainnya, kemudian saling bersama untuk mencapai tujuan. Sistem memiliki beberapa bagian mulai dari sistem yang lebih kecil yang mendorong sistem yang lebih besar (Romney, 2015).

Perancangan sistem adalah awal penentuan proses data yang diperlukan dalam membuat atau mengembangkan sistem baru. Perancangan sistem memiliki tujuan utama yaitu untuk tercapainya kebutuhan pengguna sistem yang baru serta untuk memberikan gambaran yang nyata dan rancangan yang lengkap (Mulyani, 2017).

Informasi merupakan data yang sudah diolah sebagai format yang memiliki arti untuk penerimanya sehingga bermanfaat dalam penyimpulan keputusan saat ini dan saat yang akan datang (Heriyanto, 2018).

Sistem informasi diartikan sebagai sekumpulan bagian yang saling berkaitan, memperoleh, mengoperasi, menyimpan, dan menyebarkan informasi untuk menunjang dalam mengambil keputusan dalam suatu institusi (Hasan \& Muhammad, 2020)

Pemesanan adalah satu kegiatan penting dalam setiap instansi yang berjalan di bagian perdagangan. Dalam membantu dan mengawasi kegiatan pemesanan dan penjualan, maka dibutuhkan dukungan sistem informasi yang baik, sehingga bisa mengikuti pertumbuan perusahaan yang sedang membesar (Aman, 2021).

Penjualan merupakan aktivitas yang dilaksanakan oleh seorang penjual dalam mendagangkan barang atau jasa dengan impian akan mendapatkan keuntungan dari adanya transaksi yang terjadi dan penjualan dapat diinteprtasikan sebagai penukaran atau pemindahan kekuasaan kepemilikan atas barang atau jasa dari seorang penjual ke pembeli (Arfianto \& Nugrahanti, 2019).

Interior dapat disimpulkan, bahwa interior merupakan kesatuan dari elemen- elemen pembentuk ruang yang dirancang sedemikian bentuk sehingga menjadi sebuah tempat dimana manusia melakukan segala aktifitas dengan bertolak ukur pada kenyamanan, keamanan, dan nilai estetis (Azhar, 2013).

Gorden adalah sebagian kain yang dipakai untuk membatasi cahaya. Tirai sering diletakan di sisi dalam jendela pada bangunan untuk membatasi masuknya cahaya (Yuliandri, 2013).

Data Flow Diagram adalah pereprentrasi grafik yang mewujudkan aliran informasi dan perubahan informasi yang gunakan bagai data yang menata dari masukan dan keluaran. DFD 
tidak pas untuk membentuk sistem yang menggunakan pemograman berorientasi objek (Wildaningsih \& Yulianeu, 2019).

Tujuan dari penelitian ini ialah menghasilkan suatu sistem informasi toko gordyn berbasis java yang dapat membantu pemilik toko dalam melaksanakan pengisian data yang sesuai, menginfokan persediaan stok barang, pembuatan laporan secara efisien, dan melaukan transaksi yang akurat.

\section{METODE PENELITIAN}

Pada penelitian ini, penulis menggunakan metode deskriptif dimana metode yang mengangkat permasalahan dengan memaparkan, mengartikan dan menulis suatu kondisi lalu menyelidiki serta mengangkat kesimpulan umum dari masalah yang diangkat, atau suatu format penelitian yang memiliki tujuan untuk menggambarkan mengenai fakta atau kondisi yang terjadi di dalam perusahaan.

\section{Metode Pengumpulan Data}

Metode pengumpulan data yang dilakukan penulis untuk mendapatkan data-data informasi untuk mendukung penyempurnaan hasil dari penelitian ini antara lain:

1. Wawancara

Wawancara adalah pengumpulan data dengan mengadakan pengajuan pertanyaan dan dijawab secara langsung dengan pihakpihak yang berhubungan dengan observasi penelitian yakni industri usaha interior gordyn.

2. Observasi

Observasi adalah upaya mengamati dan mendokumentasikan hal-hal yang terjadi selama kegiatan berlangsung. Pada waktu dilakukan kegiatan, secara bersamaan juga dilakukan pengamatan tentang segala sesuatu yang terjadi saat tahap pembelajaran terjadi.

Langkah-Langkah pengembangan sistem :

Dalam pengembangan sistem informasi dalam pengolahan data Hisdu Gordyn, metode yang digunakan yaitu metode waterfall yang di mana waterfall adalah bentuk yang dibangun untuk pembangunan, membuat perangkat lunak, model berkembang secara sistematis dari satu proses ke proses lain dalam metode seperti air terjun.
Tahap-tahap pengembangan model waterfall adalah sebagai berikut :

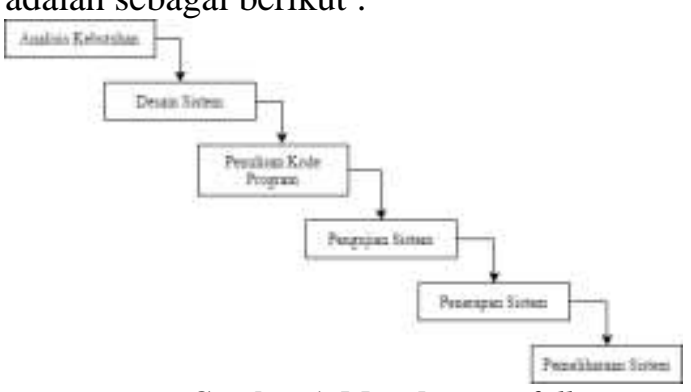

Gambar 1. Metode Waterfall

\section{HASIL DAN PEMBAHASAN}

Dari hasil penelitian yang penulis lakui maka penulis bisa menganalisa permasalahan yang ada untuk memberikan alternatif penyelesaian masalah pada hisdu gordyn yaitu :

1. Sistem Penginputan data belum menggunakan komputerisasi sehingga sering adanya kesalahan dalam proses penjualan gordyn.

2. Pembuatan laporan membutuhkan waktu pengerjaan yang cukup menyita waktu.

3. Pencarian arsip transaksi harus dengan memeriksa arsip yang sulit untuk dicari.

Gambaran dari sistem yang diusulkan pada Toko Interior Hisdu Gordyn adalah sebagai berikut:

\section{Diagram Alir Data (DAD) Sistem Diusulkan Diagram Konteks}

Berikut ini merupakan diagram konteks dalam Diagram Alir Data (DAD) sistem yang diusulkan akan digunakan pada Toko Interior Hisdu Gordyn

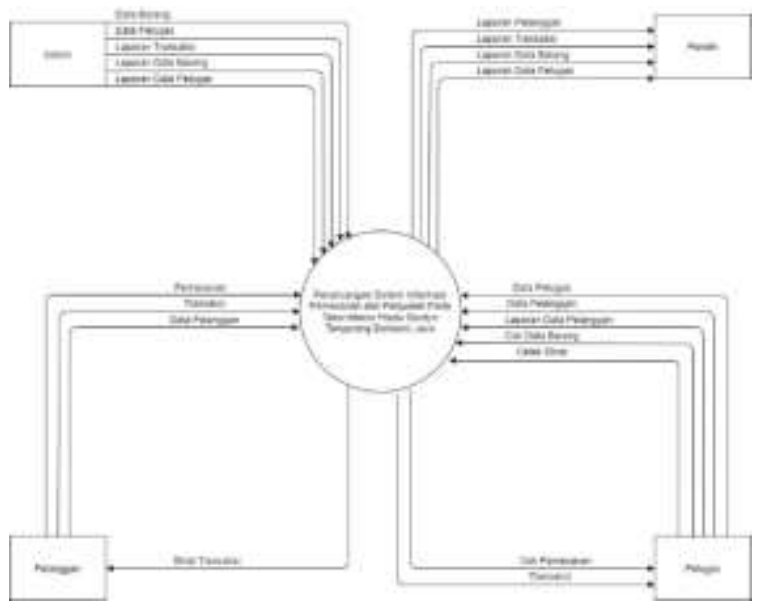

Gambar 2. Diagram Konteks Sistem yang Diusulkan

\section{Diagram Nol}

Berikut ini merupakan diagram nol dalam Diagram Alir Data (DAD) sistem yang diusulkan akan digunakan pada Toko Interior Hisdu Gordyn 


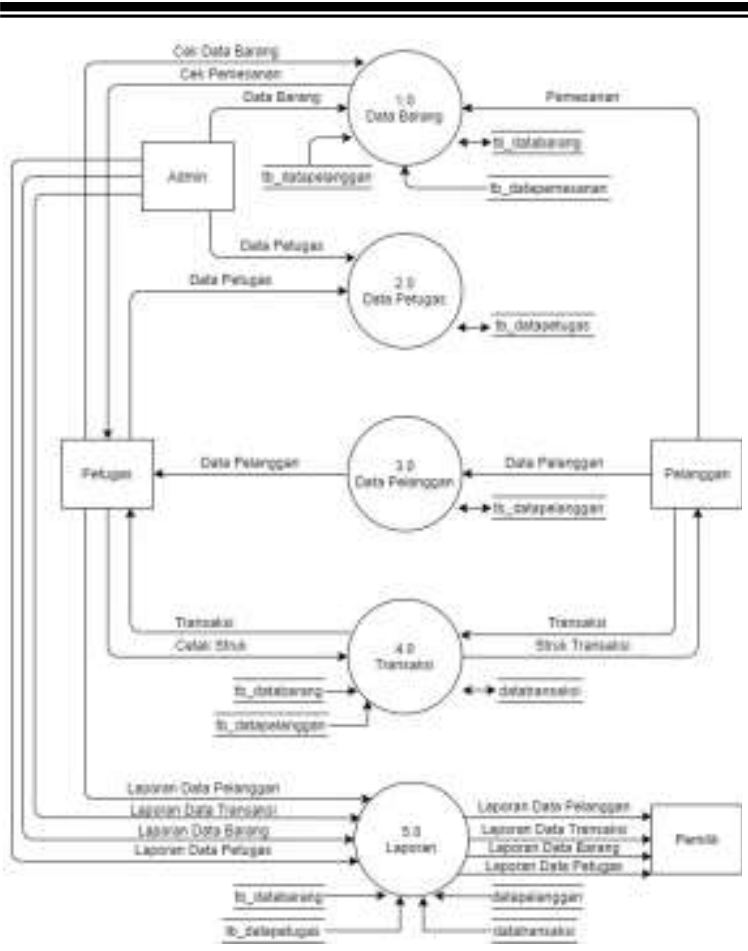

Gambar 3. Diagram Nol Sistem yang Diusulkan

\section{Normalisasi}

Berikut ini merupakan normalisasi sistem yang diusulkan akan digunakan pada Toko Interior Hisdu Gordyn

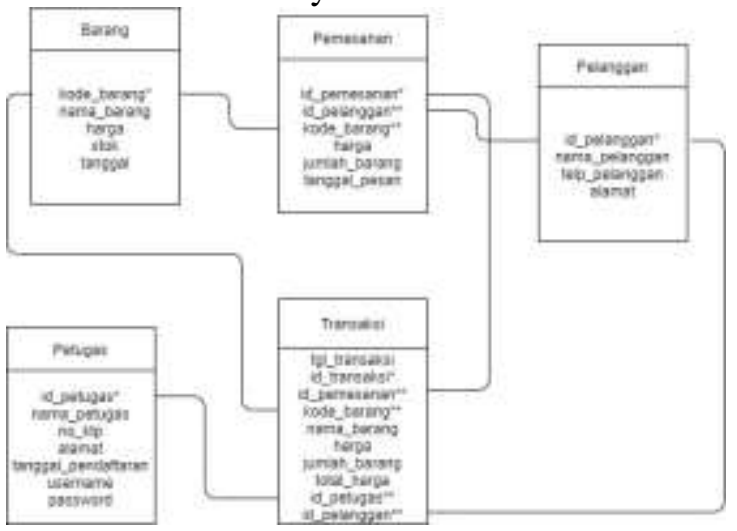

Gambar 4. Normalisasi Sistem yang Diusulkan

\section{Entity Relationship Diagram (ERD)}

Berikut ini merupakan Entity Relationship Diagram (ERD) yang digunakan pada Toko Interior Hisdu Gordyn

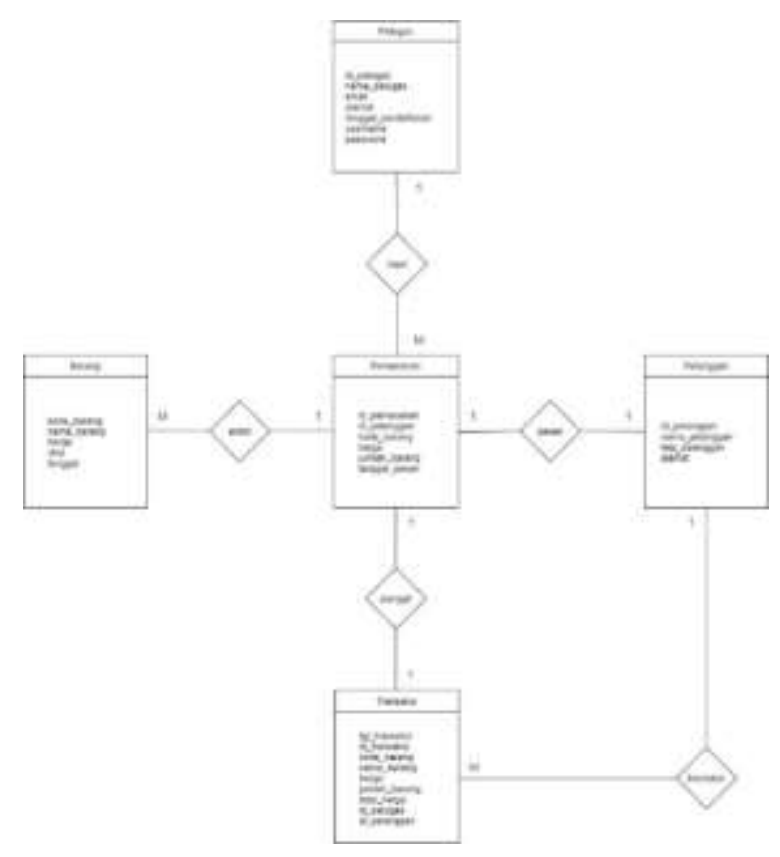

Gambar 5. Entity Relationship Diagram (ERD)

Berikut ini adalah tampilan layar dan hasil pengujian pada software program yang telah dibuat dengan bahasa pemrograman Java.

\section{Tampilan Layar Aplikasi Hisdu Gordyn} Berikut ini merupakan tampilan layar pada aplikasi Toko Interior Hisdu Gordyn

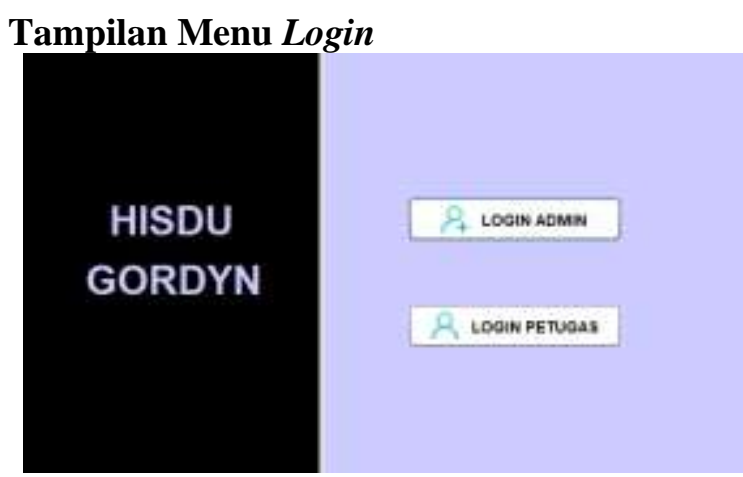

Gambar 6. Tampilan Layar Form Menu Login

Pada tampilan layar ini terdapat pada awal program yang nantinya bisa digunakan oleh admin dan petugas untuk mengoperasikan aplikasi ini 


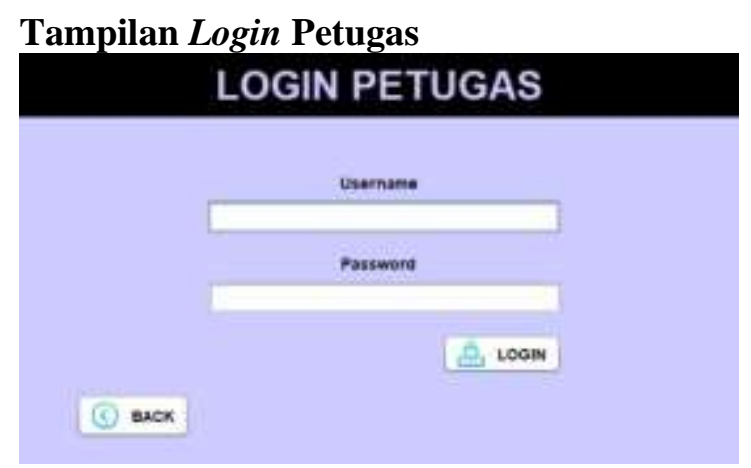

Gambar 7. Tampilan Login Petugas

Pada tampilan login petugas ini terdapat username dan password untuk masuk ke menu petugas.

\section{Tampilan Menu Petugas}

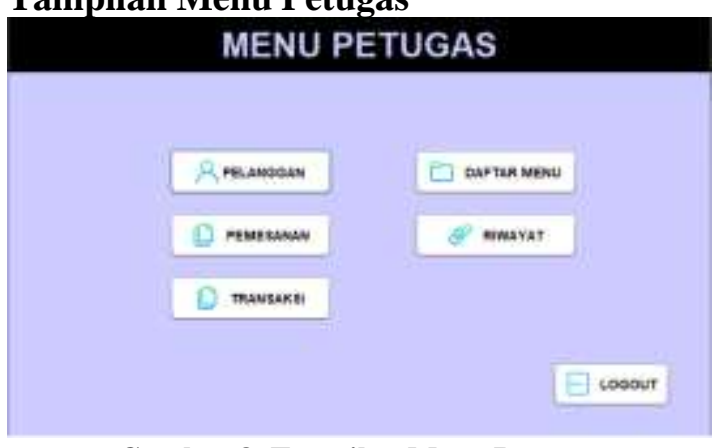

Gambar 8. Tampilan Menu Petugas

Pada tampilan Menu Admin ini terdapat 5 buah menu, pertama ada daftar menu untuk melihat barang tersedia, riwayat transaksi yang sudah dilakukan, data pelanggan untuk mendata pelanggan, pemesanan untuk pelanggan yang ingin memesan, dan transaksi untuk melakukan transaksi.

\section{Tampilan Data Pemesanan}

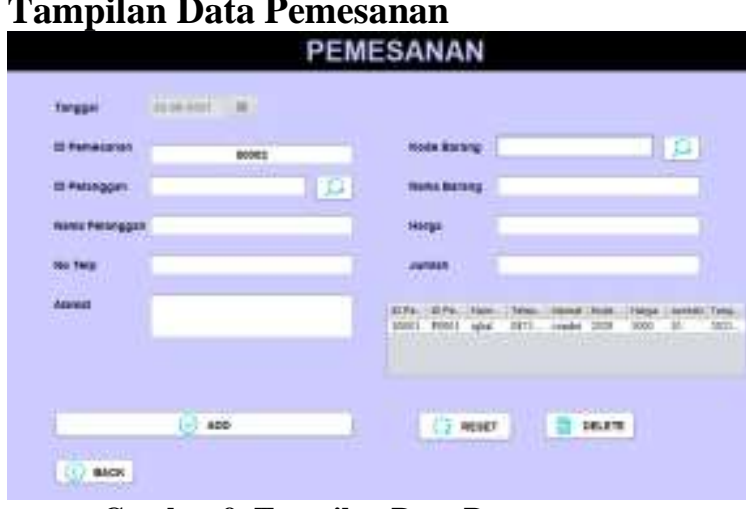

Gambar 9. Tampilan Data Pemesanan
Tampilan Transaksi

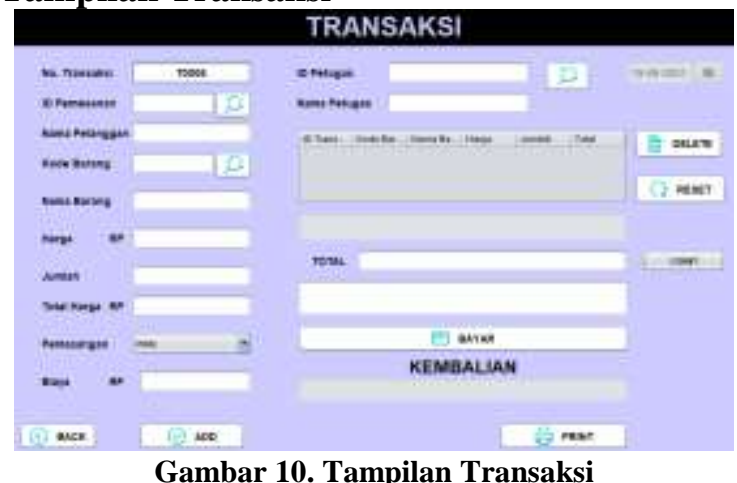

Pada layar tampilan transaksi ini bisa menginput transaksi dengan memanggil ID Pemesanan, ID Petugas, Kode Barang, lalu dengan otomatis terisi, dan bisa menambahkan biaya pemasangan. Lalu bisa melakukan transaksi yang tersedia hitungannya, dan bisa mencetak struk transaksi.

\section{Tampilan Laporan Data Riwayat Transaksi}

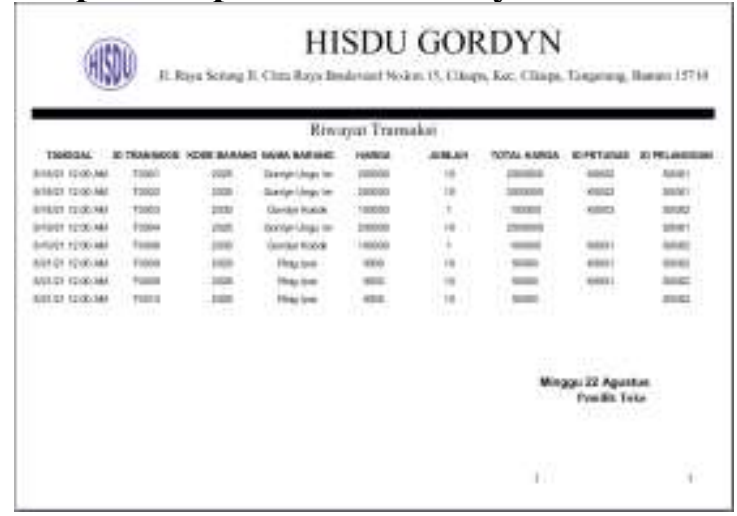

Gambar 11. Tampilan Laporan Riwayat Transaksi

Laporan data riwayat transaksi dipakai untuk melihat riwayat transaksi pada toko Interior Hisdu Gordyn. Dalam laporan data riwayat transaksi ini terdapat tanggal, id transaksi, kode barang, nama barang, harga, jumlah, total harga, id petugas, id pelanggan, tanggal pembuatan laporan, nama dari pemilik toko.

Laporan data riwayat transaksi ini nantinya akan dikeluarkan oleh admin untuk melaporkan data riwayat transaksi kepada pemilik toko.

Pada tampilan data pemesanan bisa memanggil ID Pelanggan dan Kode Barang karena bisa menginput otomatis jika sudah dipanggil. 
Tampilan Laporan Struk Transaksi

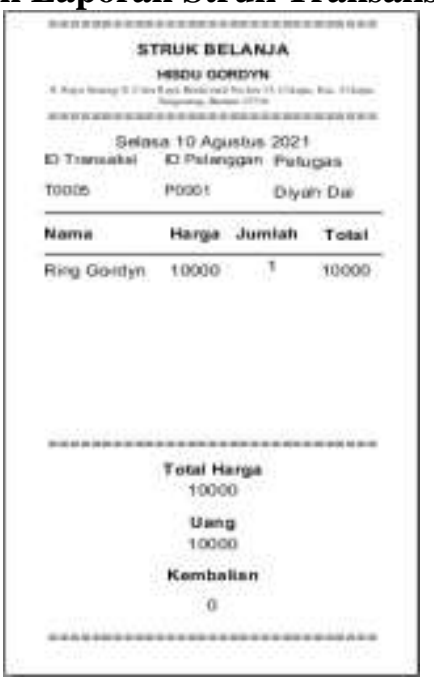

Gambar 12. Tampilan Laporan Struk Transaksi

Laporan struk transaksi ini akan diberikan oleh petugas ke pelanggan jika sudah menyelesaikan transaksi yang sudah dilakukan.

\section{SIMPULAN DAN SARAN}

Dengan adanya aplikasi sistem informasi penjualan ini membawa dampak yang baik terhadap Toko Interior Hisdu Gordyn, karena efektifitas dan efisien dapat tercapai dalam hal pengolahan persediaan stok barang yang terkomputerisasi dan penyatuan secara baik.

Sejalan dengan sistem usulan yang peneliti buat, maka demi tercapainya tujuan dan sasaran, peneliti memberi saran sebagai berikut: Perancangan Sistem pada Toko Interior Hisdu Gordyn ini perlu evaluasi secara berkala dan masih bisa dikembangkan lagi, melakukan pemeliharaan untuk menjaga kestabilan program, dan perlu adanya penambahan sesuai kebutuhan dan kerapihan dalam desain aplikasi.

\section{DAFTAR PUSTAKA}

Aman, M. (2021). Pengembangan Sistem Informasi Wedding Organizer Menggunakan Pendekatan Sistem Berorientasi Objek Pada CV Pesta. Jurnal Janitra Informatika Dan Sistem Informasi, 1(1), 47-60.

Arfianto, F. R., \& Nugrahanti, F. (2019). Rancang Bangun Aplikasi Penjualan Perumahan Berbasis Web Pada Cv. Grand Permata Residence Magetan. Prosiding Seminar Nasional Teknologi Informasi Dan Komunikasi (SENATIK), 1(1), 174-179.
Azhar, S. (2013). Sistem Informasi Akuntansi. Bandung: Lingga Jaya, 5(1).

Hasan, S., \& Muhammad, N. (2020). Sistem Informasi Pembayaran Biaya Studi Berbasis Web Pada Politeknik Sains Dan Teknologi Wiratama Maluku Utara. IJISIndonesian Journal On Information System, $5(1)$.

Heriyanto, Y. (2018). Perancangan Sistem Informasi Rental Mobil Berbasis Web Pada PT. APM Rent Car. Jurnal Intra Tech, 2(2), 64-77.

Mulyani, S. (2017). Metode Analisis dan perancangan sistem. Abdi Sistematika.

Rizky, S. (2011). 51. Soetam-BUKU AJAR: Konsep Dasar RPL. PT. Prestasi Pustakaraya.

Romney, M. B. (2015). Pengertian sistem menurut Marshall B Romney dan Paul John Steinbart. Sistem Informasi Akuntansi, 3.

Wildaningsih, W., \& Yulianeu, A. (2019). Sistem Informasi Pengolahan Data Anggota Unit Kegiatan Mahasiswa (UKM) Zaradika STMIK DCI Tasikmalaya. Jurnal Manajemen Dan Teknik Informatika (JUMANTAKA), 2(1).

Yuliandri, Eko. (2013). Fungsi Jendela Rumah Bukan Hanya Pemanis Saja

http://www.desaingambar.com/jendela-rumah/ (Diakses Pada Tanggal 23 Juli 2021) 